\title{
Vertical Tax Externalities in the Theory of Fiscal Federalism
}

\author{
MICHAEL KEEN*
}

Federal structures create the possibility of vertical tax externalities between levels of government, with the private sector's response to the tax policy decisions of one level affecting the tax base of the other. Such effects arise most obviously when both levels of government co-occupy the same tax base. This paper reviews and extends recent results on the implications of such externalities for the relationship between state and federal tax rates, the equilibrium levels of these taxes, the (ir)relevance of experience in federal countries for analyzing international tax issues, the pattern of intergovernmental grants, and the assignment of tax powers. [JEL H3, H7, H21]

It is indeed possible that a tax might be laid on a particular article by a State which might render it inexpedient that . . a further tax . . be laid on the same article by the union ... . (The Federalist Papers ${ }^{1}$ )

$\mathrm{T}$ HE ESSENCE of federalism is multileveled government. In its simplest and archetypal form - on which we shall focus - a federation comprises a single central "federal" authority superimposed on a set of lowerlevel "states." It is thus surprising to find that until recently almost all of the formal literature on fiscal federalism dealt with just one level of government, the federal government being notable by its absence.

* Michael Keen is Professor of Economics at the University of Essex, England, and currently on leave as a Technical Assistance Advisor in the IMF's Fiscal Affairs Department. This paper was written while he was a Visiting Scholar in the Fiscal Affairs Department during 1996. He is grateful to the Department for its support and hospitality; to Russell Krelove, Howell Zee, and others in the Fiscal Affairs Department for very helpful comments and suggestions; to Christos Kotsogiannis for allowing him to draw on their continuing joint work; and to Richard Bird for directing him to The Federalist Papers.

${ }^{1}$ Hamilton, Madison, and Jay (1982), p. 154. Emphasis on "inexpedient" suppressed. 
Instead, the analytical focus of writing on fiscal federalism has traditionally and typically (with rare exceptions) been on horizontal relationships between the states, and possible fiscal externalities between them: tax competition as they seek to steal tax base from one another by setting low origin-based taxes, for example, or geographic spillovers of the benefits from states' public expenditures, or problems of tax exporting as states seek to exert monopoly power in interstate markets. Thus the classic analyses of optimal tax aspects of fiscal federalism in, for example, Gordon (1983) and Mintz and Tulkens (1986) actually have no federal government present, nor does the analysis of the same set of issues, albeit from a very different perspective, in the seminal work of Brennan and Buchanan (1980). Instead, the federal government makes its appearance, if at all, only as a deus ex machina called into being to deal with the inefficiencies arising from interstate relations. It has no purposive existence in its own right, and appears, metaphorically if not literally, only on the final page of the story.

The first and most general purpose of this paper is to argue for a more substantive analytical role for the federal government than this: for a recognition that the federal government is best treated as a player in its own right, not introduced as a mechanical device for tidying the loose ends left by horizontal interactions between the states. The second and more particular purpose - the heart (and bulk) of the paper-is to develop some of the implications of a key aspect of fiscal arrangements in federations that acquires obvious importance as soon as one views the federal government in a more active light: the concurrent taxation of the same bases by federal and state governments, or, more generally, the potential dependence of the tax base of each level of government on the tax policies pursued by the other.

The opening quotation reminds us that concurrent taxation is no novelty. The authors of The Federalist Papers realized over two centuries ago that it raises important conceptual issues. Their main concern, however, was legalistic: to establish the legitimacy of both levels of government levying taxes on the same base, thereby freeing the federal government from dependence on transfers from the states. Since then, however, concurrencysynonymously, "co-occupation"- has received remarkably little attention. Though the literature on fiscal federalism does contain some discussion of the merits and weaknesses of concurrent taxation, this has typically been from an administrative perspective: see, for example, Musgrave (1983). The concern has been with such issues as the possible nuisance to taxpayers of paying distinct taxes on the same or (even worse) only slightly dissimilar bases, and on the potential trade-off between the economies of scale and scope in having a single agency collect taxes for two levels of government and the moral hazard problem that then arises if that agency owes 
primary allegiance to one level of government rather than the other. ${ }^{2}$ There has been informal recognition of some possibilities for game playing created by concurrency (see, for example, Tanzi, 1995). But the potential implications of concurrency for tax policy design and evaluation have received little systematic attention.

Recent work has started to fill this gap. In doing so it has built on important (and to some degree neglected) early contributions of Cassing and Hillman (1982), Flowers (1988), and Johnson (1988). The central purpose in much of what follows is to provide both a selective survey of, and various extensions to, this growing body of work. ${ }^{3}$

Section I of the paper addresses the first and broadest of our themes, arguing (briefly) for a more purposive view of federal government than has been usual in the literature on fiscal federalism. Sections II-VII address the second and central concern of the paper, concurrent taxation: Section II shows that concurrency is in practice a pervasive feature of fiscal reality in federal countries; Sections III-VII explore the implications for various aspects of tax policy analysis and design of the vertical tax externalities between federal and state governments to which concurrency points. Section VIII concludes.

\section{Putting the "Federal" into "Fiscal Federalism"}

At some risk of caricature, the federal government has often been seen as having two fiscal roles: redistribution across the states of the federation (whether motivated by altruism or risk sharing), and internalizing fiscal externalities that may ${ }^{4}$ arise in horizontal relations between the states. The latter function, arising from efficiency concerns and so perhaps less contentious, has received particular attention in the literature. The federal government might achieve this internalization by a variety of means. It might coordinate the decisions of the states, even perhaps abrogating such decisions to itself. Or it might leave formal decision-making powers to the states while using tax-subsidy schemes to induce the internalization of horizontal fiscal externalities between them: a system of matching grants to deal with expenditure spillovers, for example, or taxes directed to tax rates along the

${ }^{2}$ This has been an issue in Russia, for example, with federal taxes collected by an agency whose officials may feel primary loyalty to local government, and as a result reportedly vulnerable to pressure to retain federal money for regional use.

${ }^{3}$ Significant recent contributions include Besley and Rosen (1996), Boadway, Marchand, and Vigneault (1998), Dahlby (1994 and 1996), Hoyt (1996), Sobel (1997), and Wrede (1996). We also draw on the work of Boadway and Keen (1996), Keen (1995), Keen and Kotsogiannis (1996), and Kotsogiannis (1998).

${ }^{4}$ Or may not: see, for example, Krelove (1992b) and Myers (1990). 
lines of Krelove (1992a) and Wildasin (1989). The essence of all such schemes, however, is the same. In attempting to undo the consequences of horizontal externalities, the federal government seeks to bring the economy as close as possible to the (constrained) optimal unitary outcome: to the outcome, that is, which would be chosen by a benevolent policymaker enjoying access to the same information as state policymakers but unencumbered by a federal structure.

Ultimately, such a view of fiscal federalism is intrinsically unsatisfying. For if the federal government can attain the unitary outcome, and that outcome weakly dominates that which emerges from noncooperative behavior among the states, what role is left for the states to perform?

An appealing theory of federalism will explain why federal arrangements are (or are not) adopted. Considerations of asymmetric information and political economy are likely to be critical: while some "national" goods may be best provided at the federal level, for example, the appropriate provision of others may call for the elicitation of local information by more decentralized means. More generally, a key ingredient of any coherent theory of fiscal federalism must be a clear understanding of the interaction between federal and state governments, an interaction that has commonly been neglected in the traditional literature. Recognition of the need to understand these interactions has led to two distinct (as yet) strands in recent research on fiscal federalism. One has emphasized asymmetries of information between federal and state governments, and examined the implications of this for the potential for beneficial intervention by a federal authority: see, for example, Bordignon, Manasse, and Tabellini (1996), Cornes and Silva (1996), Laffont (1995), Lockwood (1996), and Raff and Wilson (1997). The second has emphasized vertical fiscal externalities between state and federal governments, especially those arising from concurrent tax powers. It is these latter that will be our main concern in this paper. Before turning to the specifics, however, it may be useful to spell out the broad character of the issues with which we shall be concerned.

A basic supposition in what follows is that the federal government faces no informational difficulties (other than those restricting the tax instruments available to it) but is for some reason unable to suppress the states and implement the unitary optimum directly. If it is able to commit to its tax policies, and has enough independent tax instruments available to it, one would expect it to be able, nevertheless, to replicate the unitary optimum indirectly, by an appropriate pattern of corrective taxes and subsidies. In this benchmark case there is clearly a sense in which the interaction between federal and state governments is trivial: the former is in effect able to see through and perfectly manipulate the latter. Even in this case, however-which is that on which most of the literature has focused, if often 
only implicitly-questions of interest arise concerning the precise nature of those corrective taxes: the role of matching grants in this context is well known, for example, but we shall see that issues also arise concerning the optimal extent, and indeed direction, of transfers between state and federal governments.

Further issues arise from a variety of possible imperfections precluding replication of the unitary outcome:

- The federal government may simply not have enough independent instruments available to it to replicate the unitary optimum. It may be restricted, for example, in the direction or extent of the vertical transfers between levels of government it can make. Or restrictions on its ability to differentiate taxes across regions-rooted perhaps in some notion of interregional equity - may prevent its achieving the degree of interregional diversity that a unitary government would wish. How do such restrictions affect its optimal policy?

- Though the asymmetry between there being several state governments but only a single federal government naturally leads one to think of the federal government as behaving as first mover, other models of federalstate interaction may be more reasonable in particular circumstances. Whether the federal government is better able to commit to its policies than state governments is by no means always clear. In Russia, for instance, several of the oblasts have apparently been capable of committing to quite aggressive policies toward the federal government. Dahlby (1996) notes, to give another example, that the federal government in Canada derives 40 percent of its revenue from a single province, Ontario, creating a dependence that may enable Ontario to exhibit some aspects of a leader. There are many obvious alternatives to viewing the federal government as first mover: it may be, for example, that it is best regarded as playing Nash in its dealings with the states. Or it may be that the relationship is best seen in a bargaining framework, or in the context of a repeated game. What differences do alternative views of the strategic character of the interaction make for policy evaluation?

- Even if the federal government acts as a Stackelberg leader, it may not be benevolent: distortions may thus arise from its own decisions, and questions arise as to the (quasi-)constitutional devices that might best be deployed to overcome these.

In what follows, we shall address instances of each of these issues. While the analysis will remain open to the basic criticism raised above-the 
existence of a federal structure will be assumed rather than explained-the framework does enable a constructive focus on some neglected aspects of federal-state interactions. It is one such set of interactions, those arising from concurrent taxation, that occupies us for the remainder of the paper.

\section{How Pervasive Is Concurrent Taxation?}

By "concurrent taxation" is here meant something more than a mechanical sharing of tax revenues across levels of government. Rather, we use the term to refer to a situation in which distinct levels of government exercise some discretion in levying taxes on substantially the same base. In Germany and Russia, for example, VAT revenues are shared between the federal and state governments in fixed proportions, with rate and base set by the federal government: the states have no real tax policy powers, so this is not an example of concurrency. On the other hand, in Russia, Canada, and the United States, both federal and state governments tax corporate income, with each exercising some discretion in the rate of taxation: this is concurrent taxation. There may be restrictions on the tax powers of either of the levels: in Russia, for example, there is an upper bound of 22 percent on the profit tax set by the states. There may be linkages between federal and state taxes: in the United States, state corporate taxes are deductible against federal. It is the existence of some core margin of discretion at each level that is of the essence.

Assessing the extent of formal concurrency is not trivial. Attributions of revenue across levels of government (as provided in OECD (1994), for example) are insufficient, since they cannot distinguish between mechanical tax sharing and genuine concurrency of powers. Accurate assessment of the extent of concurrency requires a detailed knowledge of the allocation of tax powers, and thus becomes a substantive undertaking.

Table 1 reports some highly impressionistic figures for three major federations; details behind the calculations are given in Appendix I. The numbers given are the percentages of each level's revenue raised by taxes of the various kinds: 70 percent of the provinces' income in Canada, for instance, comes from taxes co-occupied by provincial and federal governments. The figures are merely indicative, but thus interpreted leave little doubt as to the practical importance of concurrency.

It should be emphasized too that there is an important distinction to be made between formal and effective concurrency. While Table 1 seeks to measure the former, it is the latter that matters for tax policy purposes. Moreover, it is clear that formal concurrency must understate effective, and indeed may do so by a substantial margin. For example, suppose that the 
Table 1. Concurrency and Sharing Arrangements in Selected Federations (In percent)

\begin{tabular}{|c|c|c|c|c|c|c|}
\hline & \multicolumn{2}{|c|}{ Canada } & \multicolumn{2}{|c|}{ Russia } & \multicolumn{2}{|c|}{ United States } \\
\hline & Provinces & Federal & Oblasts & Federal & States & Federal \\
\hline Co-occupied & 70 & 96 & 42 & 30 & 44 & 97 \\
\hline Shared & 0 & 0 & 17 & 43 & 0 & 0 \\
\hline $\begin{array}{l}\text { Single occupation: } \\
\text { With discretion } \\
\text { No discretion }\end{array}$ & $\begin{array}{l}5 \\
0\end{array}$ & $\begin{array}{l}4 \\
\ldots\end{array}$ & $\begin{array}{r}2 \\
15\end{array}$ & $\begin{array}{c}10 \\
\ldots\end{array}$ & $\begin{array}{r}21 \\
0\end{array}$ & $\begin{array}{c}3 \\
\ldots\end{array}$ \\
\hline Transfers & 25 & 0 & 15 & 0 & 35 & 0 \\
\hline
\end{tabular}

Source: Author's calculations, described in Appendix I.

states (and only the states) can levy a general sales tax, while the federal government (and only the federal government) can impose a proportional tax on wage income. Suppose too that these are the only taxes in the economy. Formal concurrency is then clearly zero. Yet it is well known that (at least with perfect capital markets) the two taxes are exactly equivalent: effective concurrency is complete. With capital market imperfections, exact equivalence fails; but some overlap clearly remains. Or, to take another example (which will be used again below), consider a small open economy in which the only relevant factors of production are capital, perfectly mobile internationally, and land, fixed in supply and immobile both internationally and across states. Imagine that the federal government can impose a sourcebased tax on capital and the states a tax on land rents. Again, formal concurrency is zero. But the burden of a source-based tax on capital must fall entirely on land, since the net return to capital is fixed in the world market. Taxes on capital and land are not precisely equivalent — unless the demand for capital is perfectly inelastic, the former has a distortionary effect on factor employment that the latter does not-but there is some intrinsic commonality. It seems hard, indeed, to conceive of federal tax arrangements that do not involve some degree of effective concurrency.

\section{How Do State Tax Rates Respond to Federal Tax Rates?}

One set of issues that immediately presents itself when distinct levels of government occupy the same tax base concerns the way in which the policy pursued by one level affects that pursued by the other. Most obviously, should one expect an increase in the federal tax rate to eventually lead to higher state taxes or lower? Do federal taxes crowd out state taxes, or do they crowd them in? 
The question is one of obvious practical importance. In considering the 1996 cut in the federal gas excise in the United States, for example, some view was presumably taken (or at least should have been) as to the likely reaction of those who set the state gas excises. Yet, with the exception of Boadway and Keen (1996) (in passing) and Besley and Rosen (1996) (in more detail), little attention-either theoretical or empirical-has been given even to the likely direction of effects. Here we consider these in the simple case in which only one good is or can be taxed. ${ }^{5}$ To fix ideas on this and other issues to be taken up in the paper, a simple running example will help. Suppose then that the co-occupation is of some indirect tax base, with both levels of government taxing the same commodity. For simplicity, add two heroic assumptions, which will be relaxed at various points in the discussion: that states are identical, each consisting of a single consumer (implying that only efficiency issues will arise); and that the tax base is completely immobile across states (so horizontal tax competition between the states plays no role in the determination of tax rates). Preferences are characterized by an indirect utility function of the form ${ }^{6}$

$$
v(q)+\Gamma(g, G),
$$

where $v(\cdot)$ and $\Gamma(\cdot)$ are strictly concave, $g$ and $G$ are the quantities of state and federal public goods, respectively, and $q$ is the consumer price of the taxed good. Additivity in (.) greatly simplifies matters: it implies, not least, that the demand for the taxed good, ${ }^{7} x(q)=-v^{\prime}(q)$ (by Roy's identity), is independent of public expenditures. Taxes are levied in specific form, so that $q=p+t+T$, where $p$ denotes the producer price (assumed constant) while $t$ and $T$ are the state and federal tax rates, respectively. Note that we assume the two taxes to be additive; this seems natural enough in the context of indirect taxation, but - with other contexts rather more in mind-we shall touch below on some of the implications of deductibility.

Imagine then-as we shall throughout - that states play Nash relative to the federal government, with each, when setting its $t$, taking $T$ and $G$ as

${ }^{5}$ Boadway and Keen (1996) touch on the impact of a federal labor tax on the state labor tax, but do not examine this in any detail. Besley and Rosen (1996) consider the case in which the state government needs to raise some fixed amount of revenue and there are many taxed goods. The purpose here, in contrast, is to develop the most fundamental aspects of the issue in some detail by casting co-occupation in its starkest form: federal taxation is allowed to affect the overall of expenditure chosen by the states, which is financed by a single instrument. This sharp focus leads to insights that are both new and basic, the most notable being the log convexity condition derived below.

${ }^{6}$ For brevity, we simply normalize the private marginal utility of income to unity and absorb unchanging lump-sum income into the form of $v(\cdot)$.

${ }^{7}$ Derivatives are indicated by a prime for functions of a single variable and by subscripts for functions of several. 
given (an assumption that will be discussed further). The question of interest is then how a change in $T$ affects the states' choice of $t$. Does an increase in the federal tax lead to a lower state tax rate (so that the two are strategic substitutes) or to a higher one (so they are strategic complements)?

Consider first the case in which the state government is a leviathan of the type famously depicted by Brennan and Buchanan (1977), and so seeks simply to maximize its tax revenue ${ }^{8} \operatorname{tx}(q)$. The best response of the state government to an arbitrary federal tax is then implicitly defined by the familiar inverse elasticity rule that characterizes the revenue-maximizing tax rate:

$$
\frac{t}{q}=\frac{1}{e(q)}
$$

where $e(q)>0$ denotes the price elasticity of demand. To see how the revenue-maximizing $t$ characterized by equation (2) is affected by an increase in $T$, consider Figure 1. The initial equilibrium is at $A$ with a federal tax of $T_{0}$ inducing a revenue-maximizing state tax of $t_{0}$. Suppose now that the federal tax increases to $T_{1}$. Leaving the state tax unchanged would take the state to $A^{\prime}$. Thus the question is whether the equality in (2) would then continue to be satisfied at the higher consumer price associated with $A^{\prime}$ or whether $t$ needs to be raised or lowered to restore it.

It is not too hard to see that $t$ will generally have to change to restore equation (2), and-more particularly - that the direction in which it must change is uncertain. This can be seen from two simple examples:

- If the elasticity of demand is constant, an increase in $T$ will leave the right-hand side of (2) unchanged. But it also lowers the left, so $t$ must rise to restore the equality: thus, $d t / d T>0$.

- Suppose instead that the demand curve is linear. To analyze this case it is useful to rewrite equation (2) as

$$
t=-\left(\frac{1}{\frac{x^{\prime}(q)}{x(q)}}\right) \text {. }
$$

With $x^{\prime}$ constant, an increase in $T$ reduces the right of equation (3): hence, $d t / d T<0$.

${ }^{8}$ Notice that any grants received or paid by the state government are here assumed independent of its tax decisions, a point to which we shall in due course return. 
Figure 1. The Effect of a Higher Federal Tax on the Revenue-Maximizing State Tax

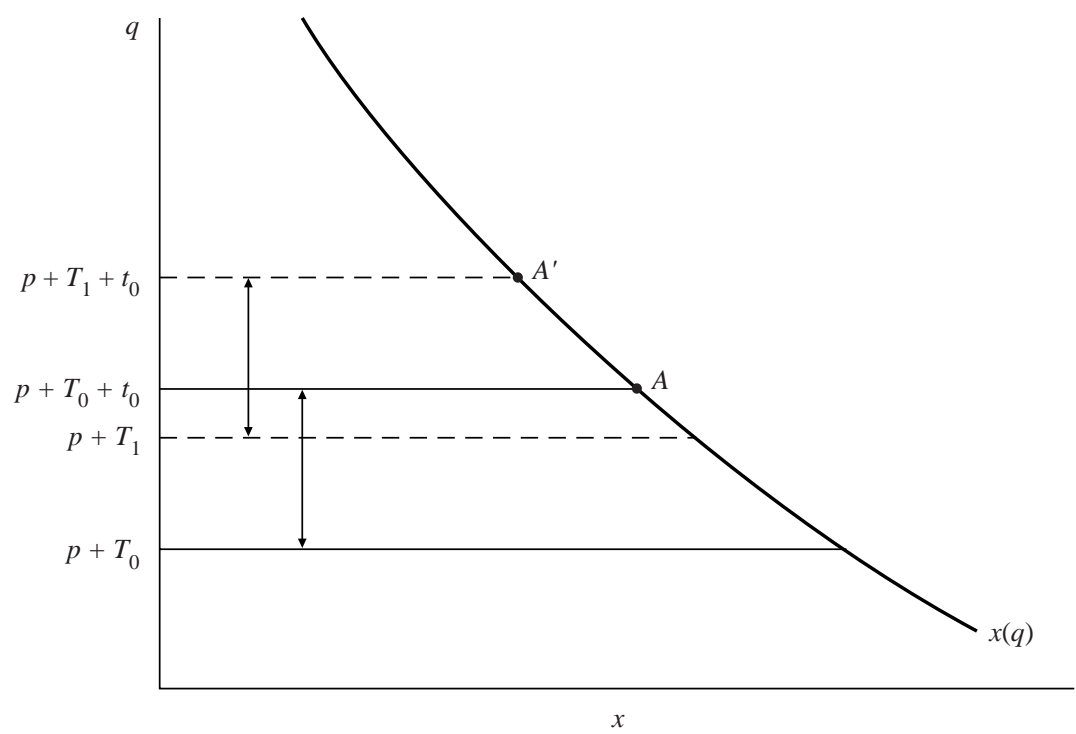

Thus $d t / d T$ can quite plausibly take either sign. What matters is the way in which the elasticity of demand varies along the demand curve. ${ }^{9}$ More precisely, what matters - as is evident from equation (3) — is whether $x^{\prime}(q) / x(q)$ (the derivative of $\ln x(q)$ ) increases or decreases with $q$. Indeed, it is immediate from equation ( 3 ) that the necessary and sufficient condition for $d t / d T$ $>0$ when the state government is a leviathan is that $x$ be log convex in $q .{ }^{10}$ Though analytically pleasing, however, log convexity is not especially amenable to intuition: as the two examples above indicate, it is not immediately apparent how likely it is to be satisfied in practice. Convexity to the origin of the demand curve itself is necessary for log convexity, for example, but is not sufficient.

${ }^{9}$ The analysis is much more complex, it should be noted, when demand for the taxed good depends on public expenditures: the rule (3) must then be amended to reflect such feedback effects, which also imply that changing $T$ will cause the demand curve in Figure 1 to shift. The sign of $d t / d T$ will then depend not only on the $\log$ convexity condition in the text but also on such imponderables as the effects of $g$ and $G$ on the slope of the demand curve. (For completeness, note that the independence of demand from $g$ and $G$ at issue here does not require quite such a strong condition as that in equation (1): it is enough that indirect utility be of the form $V[v(q), \Gamma(g, G)]$.

${ }^{10}$ This result continues to hold if the state tax is deductible against the federal; proof available from the author on request. 
Suppose now that the state government is benevolent, in the sense that it sets $t$ with the aim of maximizing the consumer's welfare, taking account of the valuation that the consumer places on the state public good (but ignoring the impact of its decisions on the provision of the federal public good $G$ ). This case is analyzed in Appendix II, but the essentials are easily described. The effect just discussed will still operate-state revenue continues to matter, though now because it finances the provision of $g$, not because of the policymaker's self-interest—but two additional effects of an increase in the federal tax come into play:

- The increased consumer price reduces demand for the taxed good, which in turn reduces the welfare loss that the consumer suffers from any given increase in the state tax.

- The reduction in $g$ (induced, at constant $t$, by the contraction of the shared tax base) increases the marginal valuation of the state public good, which makes increasing the provision of $g$ by raising $t$ more attractive than would otherwise be the case.

Both effects point toward $d t / d T>0$. Although the ambiguity of the revenue effect emphasized above continues to make the overall effect ambiguous, a concern of state policymakers with welfare (rather than just revenue) thus makes it more likely that an increase in the federal tax will induce an increase in the state tax; that is, $t$ and $T$ are more likely to be strategic complements. This intuition is verified formally in Appendix II: it is shown there that when policymakers are benevolent it is sufficient for $d t / d T>0$, but is not necessary that demand be log convex. ${ }^{11}$

Deductibility of the state tax against the federal tax makes it still more likely that $d t / d T>0$. Denoting state and federal taxes in ad valorem form ${ }^{12}$ by $t^{\mathrm{v}}(=t / p)$ and $T^{\mathrm{v}}$, the consumer price is then $p\left[1+T^{\mathrm{v}}+t^{\mathrm{v}}\left(1-T^{\mathrm{v}}\right)\right]$. Thus, one effect of an increase in the federal tax is to reduce the increase in the consumer price induced by a state tax increase, which in turn reduces both the associated welfare loss of the consumer and the dilution of state tax revenues through reduced demand. The overall effect, of course, remains uncertain, with log convexity again sufficient for strategic complementarity.

The theory being ambivalent, the sign of $d t / d T$ thus becomes an empirical matter. This too has received virtually no attention. Besley and Rosen (1996) report preliminary results that indicate for the United States a strong

${ }^{11}$ This result assumes $\Gamma(g, G)$ to be additive.

${ }^{12}$ Since $p$ is constant, ad valorem and specific taxes are equivalent in the present context (as can be seen by simply setting $p=1$ in the discussion that follows): nevertheless, deductibility is most easily thought of in terms of ad valorem taxation. 
and positive effect of federal gas and cigarette excises on state taxes. Boadway and Hayashi (1997) examine corporate tax interactions between federal and provincial governments in Canada. More work of this kind is clearly needed.

Given the paucity, as yet, of direct empirical evidence, one might hope to find some indirect evidence on this point from the somewhat more sizable empirical literature on the effect on the U.S. states of deductibility of state taxes against federal taxes. ${ }^{13}$ But the analogy between an increase in the federal tax rate and a reduction in the degree of deductibility is imperfect. For example, when the state government is a leviathan, an increase in the extent of deductibility unambiguously increases the state tax rate,${ }^{14}$ though the effect of an increase in the federal tax rate has been seen above to be ambiguous. There are some limited conclusions that one might in principle be able to draw from studies of the impact of deductibility: for instance, in a simple model along the lines of that in Section II, a negative impact of the extent of deductibility on the state tax rate would imply that $d t / d T>0 .{ }^{15}$ But such links are weak, and it seems that no very useful inferences can be drawn from these studies for the question raised here.

\section{Do Federal Structures Lead to Excessively High Tax Rates?}

Concurrency creates an evident vertical fiscal externality between levels of government: the base of each depends, through the responses of the taxed sector, on the rate set by the other. ${ }^{16}$ In the example of the previous section, a small increase in the state tax reduces federal revenues by $T x^{\prime}$, and a small increase in the federal tax reduces state revenues by $t x$ '. The rest of the paper explores some of the implications of this simple "vertical" tax externality between state and federal governments. We start by considering in this section the implications for the level of taxation. ${ }^{17}$

${ }^{13}$ See, for example, Feldstein and Metcalf (1987).

${ }^{14}$ Denoting by $\lambda$ the proportion of state taxes that are deductible against federal taxes, maximizing state revenue $t x[P+T+t(1-\lambda T)]$ gives the necessary condition $x(P+T+\alpha)+\alpha x^{\prime}(P+T+\alpha)=0$, where $\alpha \equiv t(1-\lambda T)$. Thus, an increase in $\lambda$ will induce the state to adjust $t$ so as to keep $\alpha$ constant, and hence $d t / d \lambda>0$.

${ }^{15}$ The proof of this is available from the author on request.

${ }^{16}$ Additional externalities may arise simply from the deductibility or crediting of tax payments to one level against payments to the other; our focus, however, is on effects arising from behavioral responses.

${ }^{17}$ This discussion, and that in Section V, draws in particular on Dahlby (1994), Flowers (1988), Keen (1995), and Keen and Kotsogiannis (1996). See also Wrede (1996). 
Consider first the simplest possible case. Suppose still that the tax base is completely immobile across states. Suppose too that each government, state and federal, holds Nash conjectures as to the behavior of every other government, taking as given both their tax rates and their expenditures. For a state (for example) to take both $T$ and $G$ as given in this way-as was assumed in Section III-is of course in an important sense unreasonable: since state tax policy will generally affect the federal tax base (this indeed is the essence of the issue), such a conjecture admits the possibility of the federal revenue constraint being violated. It would be straightforward to deal with this by having the state take only, say, $T$ as given and have $G$ follow from the federal revenue constraint. For present purposes it is a natural simplification to rationalize their taking both $T$ and $G$ to be constant by imagining there to be so many states that each has a negligible effect on the federal tax base. The same argument cannot be applied to federal decision making, of course, and we shall address this shortly by turning to a view of federal behavior that reflects the intrinsic asymmetry between the two levels.

Our starting point is thus a world in which each level of government completely ignores an adverse impact that raising its tax rate has on the other. The citizens of such a federation, it is easily shown, will be overtaxed, in equilibrium, by both their state government and the federal government: that is, starting at the Nash equilibrium, welfare would be increased by a small cut in either (or both) the state tax rate or the federal tax rate. This is seen most clearly (and in a way that will also prove useful later) by noting that the state government will set $t$ and $g$ so that ${ }^{18}$

$$
\Gamma_{g}=\left[1-\left(\frac{t}{q}\right) e(q)\right]^{-1} \equiv M C P F .
$$

The left-hand side of equation (4) is just the marginal value to the consumer of an additional dollar spent on the state public good. This is then equated, in the Nash equilibrium, to the marginal loss that, in the perception of the state policymaker, the consumer suffers from the tax increase needed to finance that additional dollar of $g$ : the "marginal cost of public funds" (MCPF). ${ }^{19}$ In evaluating the MCPF that it faces, the state government recognizes only the erosion of its own tax base induced by a higher tax rate.

${ }^{18}$ This is simply a rearrangement of the necessary condition for the state's choice of $t$ to maximize $v(p+t+T)+\Gamma(t x(q), G)$, which is obtained by setting $\mu=1$ in equation (A1) of Appendix II.

${ }_{19} \mathrm{~A}$ unit increase in $t$ increases state revenue by $x+t x^{\prime}$ and reduces welfare by $-v^{\prime}(q)=x$ : welfare loss per dollar of state revenue, at the margin, is thus given (after rearrangement) by the right-hand side of equation (4). 
The true, "social" marginal cost of public funds, however, recognizes also the erosion of the federal tax base, and so is given by

$$
S M C P F \equiv\left[1-\left(\frac{\tau}{q}\right) e(q)\right]^{-1},
$$

where $\tau \equiv t+T$ denotes the consolidated (state plus federal) tax rate. The crucial distinction is thus that while the MCPF recognized by the state directly depends only on the state tax $t$, the social MCPF reflects the consolidated tax rate $\tau$. Clearly $M C P F<S M C P F$ in equilibrium: the states perceive an inappropriately low cost of raising revenue, and so raise too much of it. And with the federal government also playing Nash (by (temporary) assumption), an exactly analogous argument applies at that level too. Both levels of government thus set excessively high tax rates. Indeed, it is possible that the combined rate $\tau$ will be so high in equilibrium as to leave the federation on the downward-sloping part of its Laffer curve: a tax cut at either or both levels, which will certainly raise welfare, might even lead to higher consolidated tax revenue.

Such stark conclusions naturally reflect bold assumptions. Three in particular call out for relaxation.

First, we have so far ignored the possibility-traditionally a central concern, as has been noted, in the literature on fiscal federalism - of horizontal tax competition between the states. It might be, for example, that crossborder shopping between the states presents each with an opportunity to expand its tax base by undercutting the tax rate of its neighbors. This does not affect the expectation of an excessively high federal tax rate, of course. Rather, the significance of horizontal tax competition of this kind is that it would be expected, other things being equal, to result in state tax rates being too low in equilibrium: in the absence of cooperation between them, each state ignores a benefit that it conveys on its neighbors when it raises its tax rate (pushing tax base in their direction), resulting in inefficiently low tax rates. Such effects obviously continue to operate in a federal context: for any federal tax rate $T$, the equilibrium state tax will on this account be too low. In a federal setting there are thus effects pulling state tax rates in both directions: horizontal fiscal externalities point to state tax rates being too low, ${ }^{20}$ and vertical fiscal externalities to their being too high.

Which effect will dominate? While there seems to be no general answer, one key consideration - in addition, of course, to the ease of mobility of the

${ }^{20}$ There can of course be horizontal externalities pointing to excessively high state taxes; tax exporting is the most obvious example. But it is pressures toward inefficiently low taxes that are most often emphasized - tax exporting requires that subnational jurisdictions have some degree of market power, so tends to arise in somewhat special contexts-and on which we concentrate. 
tax base-is likely to be the relative importance of state and federal governments in the co-occupied tax base, which in turn is likely to reflect the relative values that consumers attach to state and federal public goods. When the federal tax rate is high, for example, the vertical externality running upward from the states to the federal government, $T x^{\prime}$, will be correspondingly large, and the vertical externality more likely to dominate. Consider, for example, the case in which all policymakers are leviathans (the discussion here being based on a result of Keen and Kotsogiannis, 1996). Tax rates, set in the pursuit by each government of maximum revenue for itself, will then follow inverse elasticity rules of the general kind in equation (2), with $e(q)$ now being the elasticity of the jurisdiction's tax base with respect to its own tax rate. Since that elasticity is likely to be lower from the perspective of the federal government than from that of the representative state government—capital, for instance, could be in very elastic supply to each state but very inelastic supply for the federation as a whole - the federal tax rate can be expected to exceed the state tax in the Nash equilibrium. The vertical externality would then be expected to dominate, with a small cut in the state tax rate increasing federal revenues by more than it reduces state revenues. Such a federation of leviathans thus finds itself, in equilibrium, unambiguously overtaxed in the sense of being on the downward-sloping part of its Laffer curve: consolidated (state plus federal) revenue would be increased by reducing either or both the state and/or the federal tax.

A second important feature of the simple story above is the assumption that the federal government plays Nash, and takes both $t$ and $g$ as given. What if it instead plays Stackelberg, anticipating the effects of its actions on the behavior of the states, and moreover-addressing the point raised above-takes full account of the states' revenue constraints? ${ }^{21}$ Here it is necessary to distinguish between the cases in which the federal government does and does not have unrestricted access to vertical transfers between the two levels of government.

If it does have such access, then the federal government can in general eliminate the effects of the vertical externality altogether, and exactly replicate the unitary outcome that it could achieve if it were able to choose, directly, the combined tax rate $\tau$ and both expenditure levels $g$ and $G$. The federal government can then set whatever federal tax rate induces a state tax such that the sum $\tau=t+T$ is precisely the optimal combined rate of the unitary optimum, and then reallocate the revenue this yields across levels so as to finance the unitary optimal levels of public spending.

${ }^{21}$ For brevity, we do not consider the intermediate case in which the government takes as given one of the state fiscal variables but recognizes that the other is tied to it by the state revenue constraint; see Keen and Kotsogiannis (1996). 
The outcome is less happy if, at the other extreme, vertical transfers between the levels of government are for some reason impossible. Starting from the Stackelberg equilibrium, a small cut in the federal tax rate clearly has no effect on welfare if the states are free to adjust along their best responses. The impact of a cut in the state tax rate depends on the precise structure of preferences $\Gamma(g, G)$ over federal and state public goods, and is in general ambiguous: but it is certainly possible that the state tax will again be too high in equilibrium. One can also ask whether welfare would be increased by cutting the federal tax if instead the state tax is held constant. For a small open federation with access only to source-based taxes on capital, Keen and Kotsogiannis (1996) show that the answer to this turns on whether state and federal taxes are strategic substitutes or complements (along the broad lines discussed in Section III). The reason for this is that smallness implies the only relevant externality to be that operating vertically ${ }^{22}$ between states and federal government, with the federal government then optimally setting its own rate so as to mitigate this externality by inducing the states to set a lower tax than they otherwise would; which implies a higher (lower) federal tax than would otherwise be set accordingly as the two taxes are strategic substitutes (complements).

But while the nature of any inefficiency in the aggregate level of public expenditure in the Stackelberg equilibrium is thus uncertain, it is shown in Appendix III that there is a clear inefficiency in its composition. Since the federal government recognizes the adverse impact that increasing its tax rate has on the state revenues but the states do not reciprocate, the federal government will perceive a higher MCPF than do the states. In equilibrium, the marginal valuation of the federal public good will consequently exceed that of the state public good: thus there will be relative underprovision of the federal public good, and relative overprovision of the state public good, in the sense that welfare would be increased (holding tax rates constant) by spending more at the federal level and less at the state level.

Third, an important role in the basic result of overtaxation is also played by the absence of any impact on the tax base of each level of the spending by the other. Suppose, for example, that the states tax cigarettes and spend the proceeds on highways, while the federal government taxes gasoline. Then an increase in the state tax might actually lead — through the route of an improved highway system leading to an increased demand for gas- to an increase in federal revenues: the vertical externality is then beneficial, not harmful, and one would consequently expect taxes to be too low in

${ }^{22}$ There then being, in effect, no horizontal competition among the states comprising the federation but only between each state and the rest of the world. 
equilibrium rather than too high. (Dahlby and Wilson, 1996, and Kotsogiannis, 1998, pursue this possibility.) More generally, vertical fiscal externalities can take several forms, and need not be damaging, a point emphasized by Dahlby (1996). In what follows, however, we continue to focus on the adverse vertical tax externality arising from concurrent taxation: for there is a fundamental commonality of the potential bases of federal and state governments - both are ultimately dependent on the extent of activity of the private sector-which seems to make some degree of tax base overlap between levels of government an almost inevitable consequence of endowing both with real tax powers.

For the reasons just given, and others, theory admits no unambiguous answer to the question of whether federal structures create an inherent tendency toward excessively high tax rates. The empirics of this issue have as yet been little explored. But the answer one finds to perhaps the first empirical question one might ask is of interest. Regressing (the logistic transformation of) the ratio of tax revenue ${ }^{23}$ to GDP $(\theta)$ of the OECD countries ${ }^{24}$ against per capita income $Y$, the share of central in total taxes $C$ (adjusted to allocate to central government revenues known to accrue to lower levels under revenue-sharing arrangements) and a dummy FED for the five federal members, one finds

$$
\ln \left(\frac{\theta}{1-\theta}\right)=\begin{gathered}
-6.8+0.8 \ln (C)+0.3 \ln (Y)-0.2 F E D ; R^{2}=0.49, N=24 \\
(5.4)(4.1)
\end{gathered}
$$

figures in parentheses being $t$-statistics. Thus, tax ratios are noticeably lower in federal countries. ${ }^{25}$ This might seem to be evidence against the suspicion that taxes tend to be too high in federal countries. But note that this suspicion, more precisely put, is that tax rates will be too high. The finding of low tax revenues in federal countries is perfectly consistent, for example, with tax rates being so high as to put them on the wrong side of the Laffer curve. Of course, no great weight should be placed on this empirical result, which is largely driven by just two observations (Switzerland and the United States). Again, much more careful work is clearly required. But perhaps the low tax ratios of federal countries are more of a puzzle than has been thought.

${ }^{23}$ Excluding social security: this does not affect the empirical point of interest here.

${ }^{24}$ Data are for 1990.

${ }^{25}$ This result is reasonably robust against changes in specification: significance of the coefficient on FED increases, for example, while the coefficient stays roughly the same, if social security taxes are included in the dependent variable. 


\section{Fiscal Federalism Versus Internationalism}

This section uses the vertical tax externality associated with concurrent taxation to provide a vivid illustration of the argument made in Section I: the importance of modeling the federal government as an active player. More generally, it establishes a fundamental - and often unrecognizeddistinction between issues of fiscal federalism and of international taxation: the presence or absence of an overarching federal government, it will be seen, makes a profound difference for tax analysis, and consequently for policy design and evaluation.

The example concerns the apparently simple question of how an intensification of horizontal tax competition would be expected to affect tax revenues. Suppose, for sharpness, that all policymakers are leviathans. The typical presumption is that an intensification of horizontal tax competition-perhaps brought about by a reduction in mobility costs between the states, or by an increase in the number of lower-level jurisdictions-will cause revenues to fall. Indeed, there has emerged an empirical literature, beginning with Oates (1972), that takes this for granted and simply seeks to identify such an effect at work.

But the purpose of this section is to suggest that this claim is by no means obviously valid: the prediction that intensified horizontal tax competition will reduce tax revenues is more likely to be correct if and only if there is no overarching federal government. That is, the notion that an intensification of horizontal competition will reduce tax revenue may be more relevant to issues of international tax competition than to the analysis of fiscal federalism.

This is shown in Figure 2. The upper panel shows the reaction functions $B B$ and $b b$ of federal and state governments respectively. The former incorporates the outcome of interstate horizontal competition: that is, $b b$ shows the equilibrium state tax rate, conditional on $T \cdot{ }^{26}$

Consider first a federal economy, initially in equilibrium at $A$. The dashed line $a a$ with slope -1 and passing through $A$ picks off the combined tax rate of the Nash equilibrium, $\tau^{N}$, on the horizontal axis. Consolidated federal and state revenues can then be read by moving down to the Laffer curve in the lower panel. Recall from the discussion in Section IV that the Nash equilibrium in such a federation of leviathans lies on the downward-sloping part of the Laffer curve. An intensification of horizontal tax competition would be expected to shift the reaction function $b b$ downward: for any given federal tax, the state tax will fall. The federal tax will also change, of course,

${ }^{26}$ The two taxes are drawn as strategic complements, but it is easily checked that this is inessential to the result: see the next footnote. 
Figure 2. The Effect of Horizontal Tax Competition in International and Federal Settings

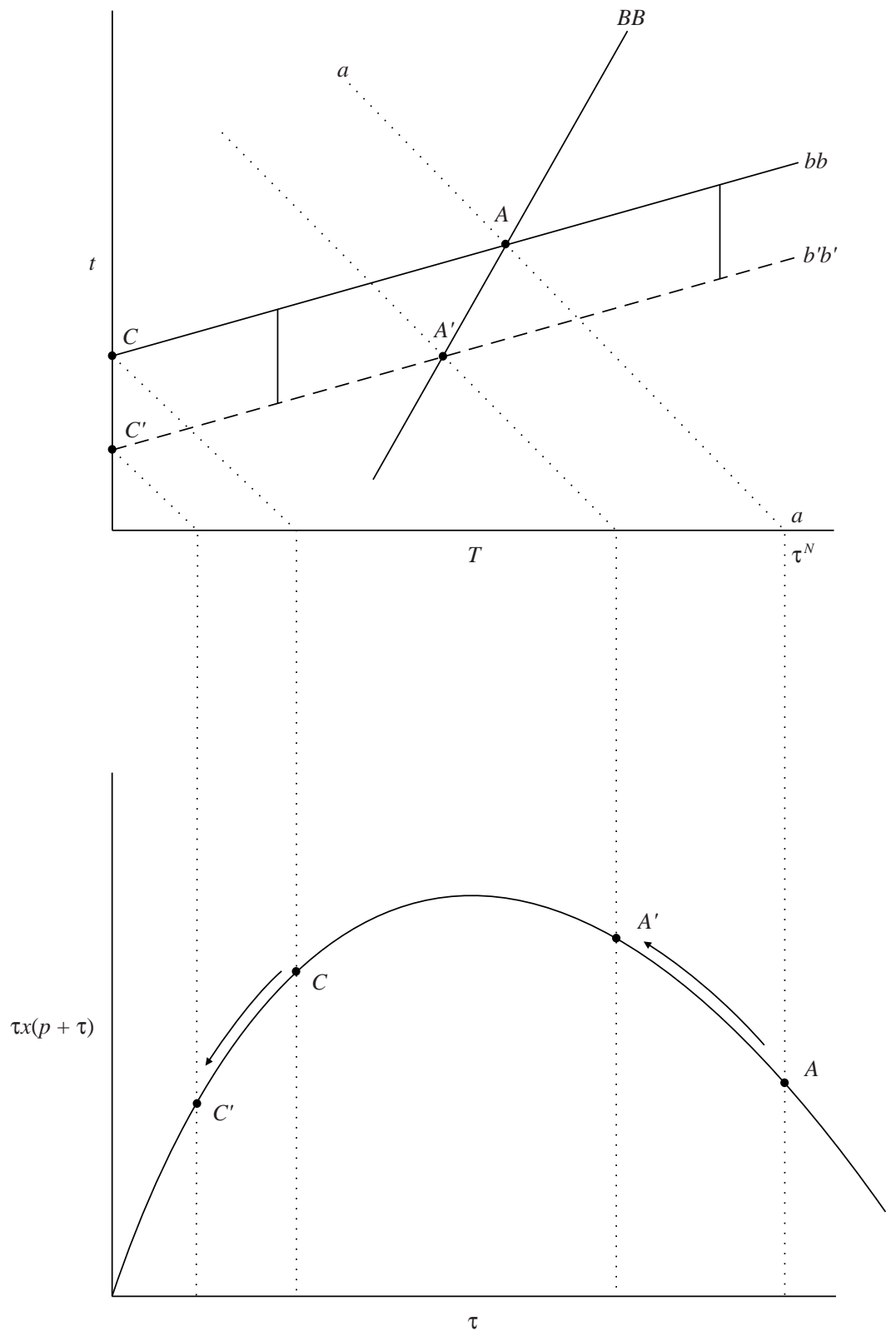


the new equilibrium being at $A^{\prime}$. As drawn, the federal tax falls, and hence so too does the consolidated tax rate..$^{27}$ But then it is immediate from the lower panel that tax revenue actually rises. That is, if policymakers are leviathans then intensified horizontal tax competition within a federation would be expected to increase tax revenue, not reduce it. And the reason is obvious: as the states compete more intensively against one another, setting lower tax rates, so the position of the federal policymaker becomes closer to that of an untrammeled monopolist.

Consider now the effects of intensified horizontal competition between independent nations: the same question as above, that is, except that now there is no federal government. Clearly, equilibrium will in this case lie on the upward-sloping part of the Laffer curve, for each state ignores a benefit that it confers on others by raising its tax rate. With $T=0$, the downward shift of $b b$ now moves the economy from $C$ to $C^{\prime}$, and so does indeed lead not only to lower tax rates but also to lower revenues.

The presence or absence of a federal government may thus make a more profound difference to the analysis of tax policy than seems to have been generally recognized. In considering the tax implications of increasing integration in the European Union, for example, great care is for this reason needed in seeking to draw lessons from the fundamentally dissimilar circumstances of North America.

\section{Vertical Externalities and Intergovernmental Transfers}

The vertical tax externality on which we are focusing also has potentially profound implications for the optimal pattern-indeed for the basic rationalization - of intergovernmental transfers. Vertical transfers between levels of government have received little analytical attention. Instead, the optimal "fiscal gap"- the excess of the federal government's revenues from own sources over its nontransfer spending - has typically been seen as merely the residual implied by the difference between the optimal degrees of centralization of tax and spending powers, perhaps modified by some notion that political accountability is best served by maintaining a reasonably close link between spending and taxing at each level of government. In "mature" Western federations, the fiscal gap is typically positive, with transfers running from federal government down to the states: this reflects, it seems, some presumption that the case for centralizing taxation is stronger than that for centralizing expenditures.

${ }^{27}$ If the two taxes are strategic substitutes, the federal tax will be higher in the new equilibrium. But stability considerations imply that the consolidated tax rate will nevertheless fall, so that the same conclusions apply. 
Recognition of the vertical externality associated with concurrent taxation immediately points to a quite different rationale for vertical intergovernmental transfers. The obvious way to eliminate this externality is to allocate all tax powers to just one level of government and finance the other by a vertical transfer. In this view, the rationale for vertical transfers is not to close the fiscal gap left by any mismatch between the optimal degrees of centralization of taxing and spending; rather, it is to avoid inefficiencies from tax base overlap.

The example of the previous section provides a striking illustration of this point. Brennan and Buchanan (1980), it may be recalled, oppose intergovernmental transfers on the grounds that they are a form of "fiscal cartelization": "[r]evenue-sharing is undesirable, because it subverts the primary purpose of federalism, which is to create competition between jurisdictions." ${ }^{28}$ Suppose though that in the context of Figure 2 above, the state leviathans were enabled to delegate their powers to the federal leviathan, who then sets the tax rate and distributes the proceeds in vertical transfers down to the state leviathans. The monopolistic federal leviathan would clearly take the economy to the peak of the Laffer curve. This would certainly allow the state leviathans to gain. But note that, since the economy is initially on the downward-sloping part of the Laffer curve, this fiscal cartelization will actually reduce the tax rate; and assuming too that at least some of the additional revenue escapes the policymakers' clutches and leads to increased productive public expenditure, ${ }^{29}$ one might thus expect the consumer to benefit from the elimination of the vertical externality and the associated introduction of vertical transfers.

Vertical transfers may thus have a useful role to play as the counterpart of an allocation of tax powers that mitigates the vertical externality from concurrent taxation. The question then immediately arises: if the vertical externality is to be removed by allocating tax powers entirely to one level of government or the other, to which level should they be given?

It is useful to distinguish between two cases:

- Suppose first that there is no horizontal tax competition between the states. Then it makes no substantive difference whether powers are given uniquely to the federal government (with transfers running from center to states) or uniquely to the states (with transfers running in the opposite direction).$^{30}$ If all tax powers are given to the federal government-as in

${ }^{28}$ Brennan and Buchanan (1980), p. 183.

${ }^{29}$ As will be the case, for example, in the model of Brennan and Buchanan (1977), which has leviathan constrained to spend some fixed proportion of tax revenues on socially productive items.

${ }^{30}$ Or, as noted in the preceding section, one could also envisage a situation in which both levels retain tax powers, with the federal government able to replicate the unitary outcome by using both its own distorting taxes and its ability to impose lump-sum taxes on the states. 
the leviathan example of just above-it will simply face the tax design problem of the unitary government. If instead they are given to the states, then the federal government-so long as it is able to impose appropriate lump-sum taxes on the state governments-can, by acting as leader, again induce the unitary outcome.

- If, however, interstate mobility of the tax base generates horizontal tax competition, then tax powers cannot be delegated entirely to the states without jeopardizing efficiency: the federal government must retain enough instruments to correct any pressure toward inefficiently low state taxes.

Even in this case, however, the internalization of vertical fiscal externalities may plausibly require a negative fiscal gap: that is, it may be optimal for transfers to run in the opposite direction to that taken for granted in the mature Western federations, upward from the states to the federal government. ${ }^{31}$

Imagine, for example, that production in each state involves combining (at constant returns) capital, perfectly mobile across the states, with land, in fixed supply and entirely immobile. Suppose too that the federal government taxes the rents from land. When a state increases its tax on capital, it reduces the employment of capital and hence rents, and hence also the federal government's receipts from the rent tax. To replicate the unitary outcome, the federal government needs to insulate its revenues from this effect of Nash behavior by the states in taxing capital; to remove the vertical externality, it must arrange for the MCPF perceived by the state to coincide with the SMCPF, and this-recalling the discussion above-requires that federal tax revenue be independent of the state tax rate. And this requires the federal government to subsidize capital, at such a rate that the loss of rent tax receipts it suffers when a state raises its tax on capital is exactly offset by a revenue gain from reduced subsidy payments to capital: depending on the extent of its rent tax receipts and consumers' preferences over federal expenditure, the federal government may thus need to extract revenue from the states to finance its expenditures on both the federal public good and the capital subsidy.

In both of these cases, a strategy of allocating all distorting taxes to the federal government combined with lump-sum transfers between the levels of government thus enables the vertical externality to be eliminated. But such arrangements may be infeasible, perhaps because of administrative difficulties in creating and motivating the bureaucracy to administer the transfers in the even-handed fashion required. When some degree of concurrency

${ }^{31}$ The discussion here draws on Boadway and Keen (1996). 
is unavoidable, an alternative means of eliminating the damaging vertical externality, pointed out by Dahlby (1996), is to impose an appropriate corrective tax on state revenues, the essence again being to so arrange matters that the MCPF perceived by the state coincides with the true SMCPF in equation (5). . $^{32}$

The question then arises (and is as yet unresolved) of how to reconcile arrangements of this kind, intended to neutralize the vertical tax externality, with another and quite different concern that, in practice, often plays a key role in shaping the pattern of intergovernmental grants: equalization across the states. And this in turn raises a further question concerning the implication of vertical externalities for the evaluation of intergovernmental grants more widely. ${ }^{33} \mathrm{~A}$ key purpose of equalization grants of the kind observed in Canada, for example, is to compensate those states whose tax base is low relative to some notion of the federation-wide average. This means, as has been pointed out by Smart (1996), that each province is to some degree insulated from the adverse effect that increasing its tax rate has on its tax base. But this insulation encourages the states to set excessively high tax rates: equalization grants may thus intensify vertical fiscal externalities.

\section{The Allocation of Tax Instruments Between Federal and State Governments}

Consider finally the implications of the vertical tax externality for the appropriate allocation of tax instruments across levels of government: for the question, that is, of which taxes should be given to which level(s) of government.

This is another issue that has received little formal analysis. Instead there has emerged something of a conventional wisdom, eloquently expressed by Musgrave (1983). This emphasizes the potential importance of both the horizontal mobility of the tax base and idiosyncratic features of political identity and history. The perception that business capital is likely to be highly mobile across states, for example, is typically taken to imply that corporate taxation is best preserved to the federal government. The appropriate allocation of taxes on natural resource rents, on the other hand-which are in practice often distributed very unequally across the states-is generally seen as turning on the relative strengths of the senses of regional and national identity.

\footnotetext{
${ }^{32}$ More precisely, Dahlby (1996) points out that by taxing away a proportion $\pi$ of state revenues, so that the state government's problem becomes that of maximizing $v(q)+\Gamma((1-\pi) t x(q), G)$, the federal government can ensure that the MCPF perceived by the state coincides with the SMCPF by setting $\pi=-(T / q) e(q) /[1+(t / q) e(q)]$ (evaluated at the optimum).

${ }^{33} \mathrm{I}$ am indebted to Robin Boadway for this point.
} 
Considerations arising from vertical tax externalities hold the prospect of new and sharper insights into the allocation of tax powers. At the most general level, as we have already seen, they create a case for minimizing the degree of overlap between federal and state tax bases. Once again, the point is nicely put in The Federalist Papers: "The particular policy of the national and of the State systems of finance might now and then not exactly coincide, and might require reciprocal forbearances." 34 A recent analysis by Hoyt (1996) neatly shows such forbearance emerging endogenously from optimizing behavior by the federal government, which chooses to mitigate vertical externalities by confining itself to a base that is horizontally mobile across states.

Complete separation of tax powers may not be feasible or indeed desirable, for reasons touched on above. But even then, of course, some allocations of tax power may do more to mitigate vertical externalities than others. This opens up an entirely new perspective on the appropriate vertical allocation of tax powers in federations, as the following two examples show.

The first concerns the allocation of taxes on resource rents. Such taxes have no distortionary effects, so that one might think their allocation to be-as in the conventional wisdom - essentially a matter of distributional politics. The potentially damaging effects of vertical externalities, however, create a potential role for pure efficiency considerations in allocating rent taxes. To see this, consider again the example of Section VI, in which the states tax mobile capital while the federal government taxes rents on land. In the discussion there, it was seen that the federal government could replicate the unitary outcome by subsidizing capital and arranging appropriate vertical transfers to itself. Suppose, however, that-to make the point as sharply as possible — only the states are empowered to tax or subsidize capital, and that corrective schemes of the type described by Dahlby (1996), and above, are also unavailable. Then the federal government is unable to replicate the unitary outcome, for it cannot then correct for each state's neglect of the adverse impact that increasing its tax rate has on federal revenues. To remove the inefficiency, the rent tax must be taken away from the federal government and given to the states. One thus arrives at a prescription for the allocation of rent taxes based not on (often rather vague) notions of political identity but on standard efficiency considerations.

The second example concerns a more general fundamental question: other things being equal, is it better for federal and state governments to cooccupy an inelastic tax base or an elastic one? Does the inelasticity of the demand for gasoline, for example, make the gas excise a good tax for federal and state governments to share, or a bad one?

\footnotetext{
${ }^{34}$ Hamilton, Madison, and Jay (1982), p. 154.
} 
It might at first seem that the best base to share is an inelastic one. Since the marginal external damage from a small increase in the state tax rate is $T x^{\prime}$, other things being equal, a small (absolute) value for $x^{\prime}$ means a small externality. But other things will not be equal. In particular, the lower the elasticity of demand, the greater-by the standard intuition from the Ramsey rule - the optimal federal tax $T$ is likely to be, and hence the larger the marginal external damage $T x^{\prime}$ will be when the federal tax is set optimally. There are thus considerations pointing in opposite directions. Which will dominate?

Return again to the running example established in Section II. To simplify, suppose further that there is only one state government, that federal and state public goods are perfect substitutes, and that the marginal utility of this composite public good is a constant $\gamma>1$. The two levels of government then being effectively identical, they will charge the same tax rate in the Nash equilibrium. That equilibrium is thus as illustrated by point $\mathrm{A}$ in Figure 3, being characterized by the condition (4) above, which now becomes

$$
\gamma=\frac{1}{1-\frac{1}{2} \tau^{N} \beta\left(\tau^{N}\right)},
$$

Figure 3. When Is Co-Occupancy Most Damaging?

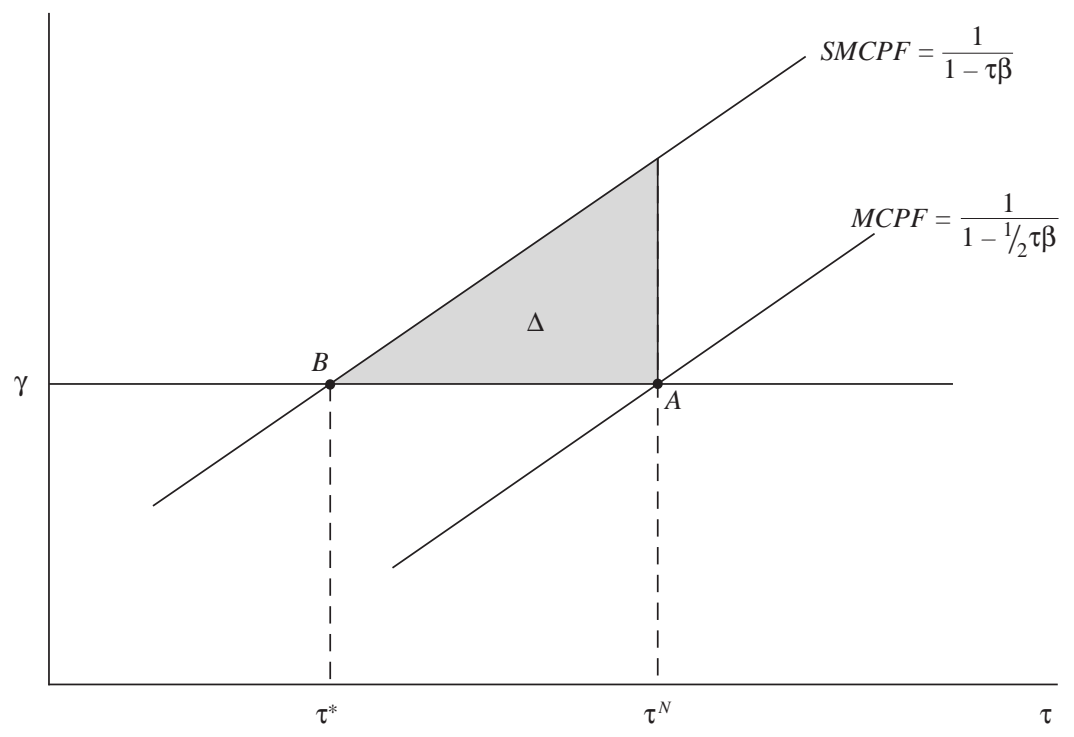


where $\beta(q) \equiv-x^{\prime}(q) / x(q)$ denotes the semielasticity of demand. The social optimum, on the other hand, is at point $B$ as characterized in equation (5) above. The deadweight loss from the inefficiently high level of taxation is thus given by the shaded area $\Delta$. The ambiguity just seen is then apparent from the figure. A reduction in $\beta$ flattens the SMCPF schedule, which tends to reduce the deadweight loss. But at the same time a fall in $\beta$ can also be seen to increase the excess $\tau^{N}-\tau^{*}$ of the combined tax rate in the Nash equilibrium over its value at the optimum, which tends to increase the welfare loss. Thus, it is not immediately clear whether an increase in $\beta$ increases or reduces the welfare loss from concurrency.

This issue is resolved, for the case in which $\beta(q)$ is constant, in Appendix IV. It is shown there that the second effect dominates, in the sense that an increase in $\beta$ reduces the deadweight loss $\Delta$. Thus, loosely speaking, the deadweight loss from concurrency is greater the less elastic is the tax base. To develop some intuition for this, note that since the marginal external damage from a unit increase in the state tax is $T x^{\prime}$, the aggregate damage from state taxation is roughly $T x^{\prime} t$; arguing similarly for the damage from the federal tax, total external damage is $2 T x^{\prime} t$. Evaluating this at some optimum in which both $t$ and $T$ are set in inverse proportion to the elasticity of demand, welfare loss is proportional to $q x / e(q)$ : for a given level of consumer expenditure, a reduction in the elasticity of demand worsens the loss from co-occupation.

This conclusion obviously rests on a series of restrictive assumptions, but may point to a powerful lesson: it suggests, for example, that the inelasticity of demand for gas argues against co-occupation of the gasoline excise.

\section{Conclusions}

The discussion here has not covered all areas of policy in which vertical tax externalities may play a significant role. They also have implications, for example, for distributional policy: Johnson (1988) and Boadway, Marchand, and Vigneault (1998) point out that vertical externalities may induce the states to undertake too much redistribution, perceiving part of the revenue cost to be passed on to the federal government and thereby to other states. Nor has the discussion covered all of the vertical externalities that can arise in federations. As noted in passing, there may be vertical fiscal externalities other than those from the kind of concurrency examined here (many of which may be beneficial). There may also be important "quasi-fiscal" vertical externalities: the federal government's decisions on civil service pay, for instance, can have a profound impact on the budgetary position of the states. It should be emphasized again that the models in mind 
here remain open to the criticism that they lack any intrinsic rationale for the adoption of a federal structure. That is, the approach has been to examine some of the implications of federal structures once they are in place, not to explain why they might emerge. Seen in that light, however, the theory of fiscal federalism might benefit from a recognition that vertical externalities between levels may be just as central to the evaluation of federal structures as the horizontal externalities traditionally emphasized, and that their proper understanding may require a deeper grasp of the relationship between federal and state governments, and the recognition of a more active role for the former, than has been usual.

\section{APPENDIX I}

\section{Notes to Table 1}

Taxes are classified as "co-occupied" only if both levels of government are judged to possess significant formal discretion. "Sharing" implies the application of a mechanical rule for allocating the revenues from a tax whose rate and base is specified centrally. Single occupation "with discretion" means that the lower level possesses significant formal discretion over rate and/or base.

Canada. The calculations, which are for 1992, are built around Table 132 of OECD (1994). Social security contributions (OECD category 2000) are excluded, as are local taxes. Income taxes (both corporate and personal, category 1000) and all taxes on goods and services (5000) are taken to be co-occupied, except that taxes on trade (5123, from Table 41) are uniquely allocated to the federal government. Property taxes are allocated to the provinces (with discretion). Transfer receipts of the provinces are from Table 9.2 of Canadian Tax Foundation (1994).

Russia. The calculations, which are for 1993, are from Table 2.1 of World Bank (1996). The profit tax, resource tax, and land tax are taken to be co-occupied. (Over 90 percent of this revenue is from the profit tax; note that there is maximum on the rate that the oblast can set, which appears typically to have been binding.) VAT and the excises are shared. The personal income tax and property tax are both allocated to the oblast, the former without discretion and the latter with. The federal government is shown as having unique control over taxes on foreign activity, though some (less than 5 percent) of this revenue seems to remain with the oblast. "Government duties" and "other tax and nontax revenue" have not been allocated to any of the categories in the table.

United States. The calculations, which are for 1992, are based on Table 152 of OECD (1994). Intergovernmental transfers are from Table C of Advisory Commission on Intergovernmental Relations (1993). Social security contributions are excluded, as are local taxes. Income taxes (both corporate and personal, 1000), property taxes (4000), and excises (5120) are taken to be co-occupied. General sales taxes (5110) are uniquely allocated to the states (with discretion), while tariff revenues (5123, from Table 61) and other taxes (6000) are single-occupied, with discretion, by state and federal governments, respectively. 


\section{APPENDIX II}

\section{The Sign of $d t / d T$}

The typical state chooses $t$ to maximize $\mu v(p+t+T)+\Gamma(t x(q), G)$, with $\mu=0$ if it is a leviathan and $\mu=1$ if it is benevolent. The necessary condition

$$
F(t, T) \equiv-\mu x+\Gamma_{g} \cdot\left(x+t x^{\prime}\right)=0
$$

implicitly defines $t$ as a function of $T$. Assuming $\Gamma(g, G)$ to be additively separable, the second-order condition $F_{\mathrm{t}}<0$ then implies that $d t / d T$ has the same sign as

$$
F_{T}=\mu x^{\prime}+\mu \Gamma_{g g}\left(\frac{t x x^{\prime}}{\Gamma_{g}}\right)+\Gamma_{g}\left(x^{\prime}+t x^{\prime \prime}\right),
$$

use having been made of equation (A1) in arriving at the second term. The first two terms of equation (A2), which both vanish when $\mu=0$, are those attributed in the text to a concern with welfare.

To establish the various results involving log convexity, note that substituting for $t$ from equation (A1), the final term in (A2) becomes

$$
\Gamma_{g} \cdot\left(x^{\prime}+t x^{\prime \prime}\right)=-\left(\frac{\Gamma_{g} x^{2}}{x^{\prime}}\right) \frac{\partial^{2} \ln x}{\partial q^{2}}+\left(\frac{\mu}{x^{\prime}}\right)\left[(x)^{2} \frac{\partial^{2} \ln x}{\partial q^{2}}+\left(x^{\prime}\right)^{2}\right] .
$$

Substituting equation (A3) into equation (A2), canceling, and collecting terms then gives

$$
F_{T}=\mu \Gamma_{g g}\left(\frac{t x x^{\prime}}{\Gamma_{g}}\right)+\frac{(x)^{2}}{x^{\prime}}\left(\mu-\Gamma_{g}\right) \frac{\partial^{2} \ln x}{\partial q^{2}} .
$$

It is immediate from this that log convexity is necessary and sufficient for $d t / d T>0$ when $\mu=0$. When $\mu>0$, sufficiency follows on noting from equation (A1) that $\mu-\Gamma_{g}<0$ (so long as $t>0$ in equilibrium, for which an Inada-type condition on the state public good will suffice).

\section{APPENDIX III}

The Misallocation of Public Expenditure in the Stackelberg Equilibrium

Anticipating the response $t(T)$ of the state government, the federal government chooses $T$ to maximize $v[p+T+t(T)]+\Gamma\{[t(T) x[p+T+t(T)], T x[p+T+t(T)]\}$. Combining the necessary condition for this,

$$
-x\left(1+t^{\prime}\right)+\Gamma_{g} \cdot\left\{t^{\prime} x+t x^{\prime}\left(1+t^{\prime}\right)\right\}+\Gamma_{G} \cdot\left\{x+T x^{\prime}\left(1+t^{\prime}\right)\right\}=0,
$$

with the necessary condition of the state (A1), gives 


$$
\Gamma_{g}=\Gamma_{G} \cdot\left(1+\frac{T x^{\prime}\left(1+t^{\prime}\right)}{x}\right) .
$$

Noting from equations (A1) and (A2) that

$$
1+t^{\prime}=1-\frac{F_{T}}{F_{t}}=\frac{1}{F_{t}}\left(\Gamma_{g g}\left(x+t x^{\prime}\right) x+\Gamma_{g} x^{\prime}\right)>0
$$

(so that the state tax can fall in response to an increased federal tax, but not by so much that the combined rate falls), it then follows from equation (A6) that $\Gamma_{g}<\Gamma_{G}$.

\section{APPENDIX IV}

The Welfare Loss from Concurrent Taxation

From Figure 3, the welfare loss is approximately

$$
\Delta \approx \frac{1}{2}\left[\operatorname{SMCPF}\left(\tau^{N}\right)-M C P F\left(\tau^{N}\right)\right]\left(\tau^{N}-\tau^{*}\right),
$$

where

$$
\begin{aligned}
& \operatorname{SMCPF}(\tau) \equiv \frac{1}{1-\tau \beta}, \\
& \operatorname{MCPF}(\tau) \equiv \operatorname{SMCPF}[(1 / 2) \tau],
\end{aligned}
$$

and $\beta$ is now assumed constant. With this simplification, the socially optimal consolidated tax rate is, from equation (5),

$$
\tau^{*}=\left(\frac{\gamma-1}{\beta \gamma}\right)
$$

while, from equation (4), the consolidated tax rate in the Nash equilibrium is

$$
\tau^{N}=2 \tau^{*}
$$

Using $1 /(1-x) \approx 1+x$ to approximate $\operatorname{SMCPF}\left(\tau^{N}\right)-\operatorname{MCPF}\left(\tau^{N}\right)$ in (A8) and (A11)-(A12) to substitute for $\tau^{N}-\tau^{*}$, one finds the loss to be

$$
\Delta \approx \frac{1}{\beta}\left(\frac{\gamma-1}{\gamma}\right)^{2},
$$

and thus decreasing in $\beta$. 


\section{REFERENCES}

Advisory Commission on Intergovernmental Relations, 1993, Significant Features of Fiscal Federalism, Vol. 2 (Washington: ACIR).

Besley, Timothy J., and Harvey S. Rosen, 1996, “States' Responses to Federal Tax Setting: Evidence from Gasoline and Cigarettes" (unpublished; London: London School of Economics).

Boadway, Robin, and Masayoshi Hayashi, 1997, “An Empirical Analysis of InterGovernmental Tax Interactions: The Case of Business Income Taxes in Canada" (unpublished; Kingston, Canada: Queens University).

Boadway, Robin, and Michael J. Keen, 1996, "Efficiency and the Optimal Direction of Federal-State Transfers," International Tax and Public Finance, Vol. 3 (May), pp. 137-55.

Boadway, Robin, Maurice Marchand, and Marianne Vigneault, 1998, "The Consequences of Overlapping Tax Bases for Redistribution and Public Spending in a Federation," Journal of Public Economics, Vol. 68 (June), pp. 453-78.

Bordignon, Massimo, Paolo Manasse, and Guido Tabellini, 1996, "Optimal Regional Redistribution Under Asymmetric Information,” CEPR Discussion Paper No. 1437 (London: Centre for Economic Policy Research).

Brennan, Geoffrey, and James Buchanan, 1977, "Towards a Tax Constitution for Leviathan," Journal of Public Economics, Vol. 8 (December), pp. 255-73.

- 1980, The Power to Tax: Analytical Foundations of a Fiscal Constitution (Cambridge: Cambridge University Press).

Canadian Tax Foundation, 1994, The National Finances: An Analysis of the Programme of Revenues and Expenditures of the Government of Canada (Toronto: Canadian Tax Foundation).

Cassing, J.H., and Ayre L. Hillman, 1982, "State-Federal Resource Tax Rivalry: The Queensland Railway and the Federal Export Tax," Economic Record (September), pp. 235-41.

Cornes, Richard, and Emilson Silva, 1996, "Transfers Between Jurisdictions with Private Information: The Equity/Efficiency Tradeoff" (unpublished; Staffordshire, England: Keele University).

Dahlby, Bev, 1994, "The Distortionary Effect of Rising Taxes," in Deficit Reduction: What Pain, What Gain? ed. by William B.P. Robson and William M. Scarth (Toronto: C.D. Howe Institute).

_ 1996, "Fiscal Externalities and the Design of Intergovernmental Grants," International Tax and Public Finance, Vol. 3 (July), pp. 397-412.

— Provision of Productivity-Enhancing Activities by State Governments" (unpublished; Edmonton, Canada: University of Alberta).

Feldstein, Martin S., and Gilbert E. Metcalf, 1987, "The Effect of Federal Tax Deductibility on State and Local Taxes and Spending," Journal of Political Economy, Vol. 95 (August), pp. 710-36.

Flowers, Marilyn R., 1988, "Shared Tax Sources in a Leviathan Model of Federalism," Public Finance Quarterly, Vol. 16 (January), pp. 67-77. 
Gordon, Roger H., 1983, "An Optimal Taxation Approach to Fiscal Federalism," Quarterly Journal of Economics, Vol. 98 (November), pp. 567-86.

Hamilton, A., J. Madison, and J. Jay, 1982, The Federalist Papers, 1787-88 (New York: Bantam Books).

Hoyt, William H., 1996, “Tax Policy Coordination and Optimal Taxation in a System of Hierarchical Governments" (unpublished; Lexington, Kentucky: University of Kentucky).

Johnson, William R., 1988, "Income Redistribution in a Federal System," American Economic Review, Vol. 78 (June), pp. 570-73.

Keen, Michael J., 1995, "Pursuing Leviathan: Fiscal Federalism and International Tax Competition," paper prepared for the International Institute of Public Finance (unpublished; Colchester, England: University of Essex).

— , and Christos Kotsogiannis, 1996, "Federalism and Tax Competition" (unpublished; Colchester, England: University of Essex).

Kotsogiannis, Christos, 1998, "Aspects of Federal Tax Competition” (unpublished Ph.D. thesis; Colchester, England: University of Essex).

Krelove, Russell, 1992a, "Competitive Tax Theory in Open Economies: Constrained Inefficiency and a Pigovian Remedy," Journal of Public Economics, Vol. 48 (August), pp. 361-75.

1992b, "Efficient Tax Exporting," Canadian Journal of Economics, Vol. 25 (February), pp. 145-55.

Laffont, Jean-Jacques, 1995, “Incentives in China's Federal Tax System” (unpublished; Toulouse, France: Institut d'Economie Industrielle).

Lockwood, Ben, 1996, "Inter-Regional Insurance with Asymmetric Information" (unpublished; Exeter, England: University of Exeter).

Mintz, Jack, and Henry Tulkens, 1986, "Commodity Tax Competition Between Member States of a Federation: Equilibrium and Efficiency," Journal of Public Economics, Vol. 29 (March), pp. 133-72.

Musgrave, Richard, 1983, "Who Should Tax, Where and What?" in Tax Assignment in Federal Countries, ed. by Charles E. McLure, Jr. (Canberra, Australia: Australian National University Press).

Myers, Gordon M., 1990, "Optimality, Free Mobility and the Regional Authority in a Federation," Journal of Public Economics, Vol. 43 (October), pp. 107-21.

Oates, Wallace E., 1972, Fiscal Federalism (New York: Harcourt Brace Jovanovich).

Organization for Economic Cooperation and Development, 1994, Revenue Statistics of OECD Member Countries (Paris: OECD).

Raff, Horst, and John Douglas Wilson, 1997, "Income Redistribution with WellInformed Local Governments," International Tax and Public Finance, Vol. 4 (November), pp. 407-27.

Smart, Michael, 1996, "Adverse Taxation Incentives in Federal-Provincial Equalisation" (unpublished; Toronto, Canada: University of Toronto).

Sobel, Russell S., 1997, "Optimal Taxation in a Federal System of Governments," Southern Economic Journal, Vol. 64 (November), pp. 468-85. 
Tanzi, Vito, 1995, "Fiscal Federalism and Decentralization: A Review of Some Efficiency and Macroeconomic Aspects," Annual World Bank Conference on Development Economics, ed. by Michael Bruno and Boris Pleskovic (Washington: World Bank), pp. 295-316.

Wildasin, David, 1989, "Interjurisdictional Capital Mobility: Fiscal Externality and a Corrective Subsidy," Journal of Urban Economics, Vol. 25 (March), pp. 193-212.

World Bank, 1996, Fiscal Management in Russia (Washington: World Bank).

Wrede, Matthias, 1996, "Vertical and Horizontal Tax Competition: Will Uncoordinated Leviathans End Up on the Wrong Side of the Laffer Curve?" Finanzarchiv, Vol. 53 (Nos. 3/4), pp. 461-79. 